\title{
Objects of Survivance: A Material History of the American Indian School Experience (Montgomery and Colwell)
}

\author{
Liza Black ${ }^{1}$ \\ Indiana University \\ 'Department of History \\ Indiana University \\ Ballantine Hall 844 \\ 1020 E. Kirkwood Avenue \\ Bloomington, IN 47405 \\ United States \\ blackli@iu.edu
}

This manuscript was accepted for publication on January 4, 2021.

\begin{abstract}
The work is a book review considering the title Objects of Survivance: A Material History of the American Indian School Experience by Lindsay M. Montgomery and Chip Colwell (Denver: University Press of Colorado, 2019).

\section{Keywords}

anthropology; assimilation; boarding schools; colonialism; education; history; material culture; museum archives.
\end{abstract}

\section{Competing Interests}

The author declares no competing interests.

\section{License}

Creative Commons BY-NC-SA 4.0

Museum Anthropology Review Volume 15,1 (Spring 2021), pp 106-109 elSSN 1938-5145 https://scholarworks.iu.edu/journals/index.php/mar Copyright (c) Liza Black 2021. All rights reserved. For editorial inquiries, e-mail: mar1@indiana.edu 


\title{
Objects of Survivance: A Material History of the American Indian School Experience (Montgomery and Colwell)
}

\author{
Liza Black \\ Indiana University
}

\begin{abstract}
The work is a book review considering the title Objects of Survivance: A Material History of the American Indian School Experience by Lindsay M. Montgomery and Chip Colwell (Denver: University Press of Colorado, 2019).
\end{abstract}

[Keywords: anthropology; assimilation; boarding schools; colonialism; education; history; material culture; museum archives.]
A uthors Chip Colwell and Lindsay M. Montgomery seek to situate the archive of Jesse $\mathrm{H}$. Bratley in the long narrative of federal policies toward Indigenous people throughout the United States in the late nineteenth century. Their perspectives con- tribute to conversations in not just museum studies but more broadly to theoretical conversations in anthropology and Native American Studies. These scholars argue that Bratley's collection deserves scholarly attention and can tell us about the surviv- ance of Native people in the nineteenth and twentieth centuries.

Influenced by Native American studies, the authors pay close attention in both the first and last chapters to Gerald Vizenor's notion of survivance to make the case that the Native students encountered by Bratley engaged in strategies of survivance to not merely endure the travails of the boarding school system but to thrive and remain vibrantly Native. The closing chapter especially pushes this analysis to challenge the transculturation model of change as well as the contact zone theoretical model. They assert that these models tend to victimize Native historical actors and render Native resistance illegible.

The chapters between these more theoretical chapters move into great detail about the life of Jesse Bratley, his wife, and their children. Having been raised by white parents with tremendous financial debt, Bratley learned to hate economic insecurity and also fostered a distaste for school. As a young man leaving the home of his parents, Bratley struggled to find work that paid middle class wages. With an incredibly weak educational record and no motivation to teach other than a steady paycheck, Bratley began working for the Bureau of Indian Affairs as a teacher to Native children. Not only that, the authors disclose Bratley's anti-Native sentiments and general disgust with Native people at the outset of his BIA career. 
From the basis of economic necessity and disdain for Native people, Bratley began teaching Native children English and vocational skills for the rest of his career. More to the point of this book, Bratley became fascinated with Native culture, especially archaeology and anthropology, and purchased hundreds of cultural objects. He also spent $\$ 82$ on a camera to photograph his students and their family members. The authors do an excellent job situating this seeming irony of Bratley's positionality as a destroyer of Native culture with his obsession with collecting Native culture within the strain of salvage anthropology. They make clear that many Americans of European descent avidly purchased cultural objects from Native people as they also participated in institutional efforts to destroy Native culture.

They frame Bratley's photography within the story of photographing Native America, comparing Bratley to men like Edward Curtis who sought to sell the images. Bratley occupied a similar space as Curtis. He intended to earn a living selling the images and objects but never made this dream come to fruition. Instead he dragged his massive collection to his various posts throughout the country and eventually to his retirement home in Florida. In the hands of his four children after his death, they too struggled with turning a profit from the archive and this is what led to their being housed at the Denver Museum of Nature \& Science.

Montgomery and Colwell should also be credited for presenting the images of Native families with their full names in the caption. This decolonizing move serves the book quite well and lends itself to another of their agendas, that of including the voices of Native descendants and descendant communities. In consulting with tribal members whose relatives attended the schools and appear in Bratley's photos, the authors demonstrate their resolve in bringing the museum into the community. While the authors made a valiant effort to include their voices, this does not take up as much space in the book as the reader might hope. For some, the book might seem to contain sporadic quotes from Native descendants rather than an analysis steeped in these types of conversations.

Objects of Survivance does a remarkable job of presenting the reader with an excellent analysis of the boarding school system and forced assimilation policies. The authors assiduously tell the story of the many developments leading up to the creation of boarding schools for Native students as well as their aftermath. Perhaps disappointing to some readers might be the authors lack of questioning of the stated goals of the white reformers who advocated these policies. Excerpts such as "The only real choice left was assimilation...The new battle required new soldiers. Schools required educators willing to run these outposts dedicated to civilizing the savages at the gates of America's future" might not offer a sufficient critique of the policies. Those looking for the word genocide will also not find it in Objects.

What the book does exceedingly well is provide stunning reproductions of Bratley's photographs and cultural objects. The book itself is made of the highest quality paper, very much situating it in the art book aesthetic. Objects returns to survivance in its concluding chapter, emphasizing yet again that "For us, the key concept is survivance, which scholars have used to understand how Indigenous people were able to preserve traditional practices and identities within contexts of asymmetrical power" (p. 197). While they refer to Amy Lonetree's work on the archive of HoChunk portraits, they do not take up her call in Decolonizing Museums (2012) to sharply and explicitly document the conditions Native people survived. The cruelty easily found in other accounts of the boarding schools is not present in this gorgeous book that insists nonetheless on the resilience of Native people. 
Today we are witnessing the grim unearthing of mass graves of Indigenous children at residential schools in Canada, only in response to the insistence of Native communities. Secretary of the Interior Deb Haaland now calls for investigations into boarding schools in the United States. A new grief now sweeps over Native America as we revisit the horrors of the boarding schools.

\section{Reference Cited}

Lonetree, Amy. 2012. Decolonizing Museums: Representing Native America in National and Tribal Museums. Chapel Hill: University of North Carolina Press.

Liza Black is a citizen of the Cherokee Nation and an Assistant Professor of History and of Native American and Indigenous Studies at Indiana University. She is the author of Picturing Indians: Native Americans in Film, 1941-1960 (Lincoln: University of Nebraska Press, 2020). With Nicholas Rosenthal, she co-edited a special issue of American Indian Culture and Research Journal focused on "Representing Native Peoples." Black is presently a Visiting Scholar at the Institute for American Culture and American Indian Studies at the University of California-Los Angeles. 